UC-702 and 721

Issued: Felunury 1994

Waste Minimization and the Goal

of an Environmentally Benign

Plutonium Processing Facility:

A Strategic Plan

K. K. S. Pillay 


\section{CONTENTS}

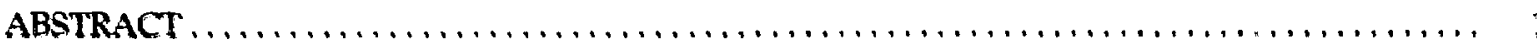

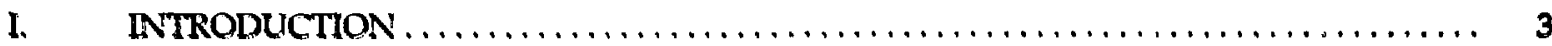

A. Relevance of This Plan to the Laboratory's Strategic Directions

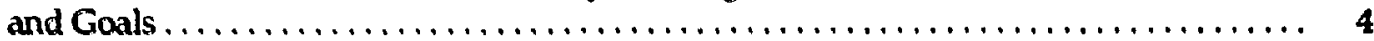

B. Potential Benefits of Applying New Jechnologies to External

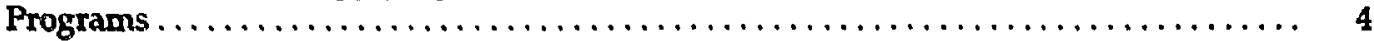

I. WASTE MINIMIZATION STRATEGIES $\ldots \ldots \ldots \ldots \ldots \ldots \ldots \ldots \ldots \ldots \ldots \ldots \ldots \ldots, 4$

II. AFPROACHES TO WASTE REDUCTION AT TA-55 $\ldots \ldots \ldots \ldots \ldots \ldots \ldots \ldots \ldots \ldots$

IV. RESEARCH AND DEVELOPMENT (R\&D) INITLATIVES $\ldots \ldots \ldots \ldots \ldots \ldots \ldots \ldots, 9$

V. A STRATEGY FOR LIQUID WASTE STREAM POLISHING $\ldots \ldots \ldots \ldots \ldots \ldots \ldots \ldots \ldots$

A. Goals and Objectives $\ldots, \ldots \ldots \ldots, \ldots, \ldots, \ldots, \ldots, \ldots, \ldots, \ldots, \ldots, 11$

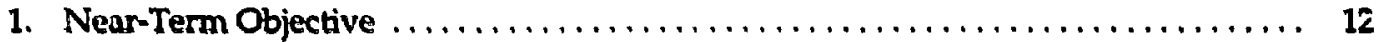

2. Long-Term Objective $\ldots \ldots \ldots \ldots \ldots \ldots \ldots \ldots \ldots \ldots \ldots \ldots \ldots, \ldots \ldots \ldots, 12$

3. Technology Demonstration Efforts $\ldots \ldots \ldots \ldots \ldots \ldots \ldots \ldots \ldots \ldots \ldots \ldots, 12$

4. Clean Option $\ldots \ldots \ldots \ldots \ldots \ldots \ldots \ldots \ldots \ldots \ldots \ldots \ldots \ldots \ldots, 13$

B. Technologies for Waste Stream Polishing $\ldots \ldots \ldots \ldots \ldots \ldots \ldots \ldots \ldots \ldots \ldots, 14$

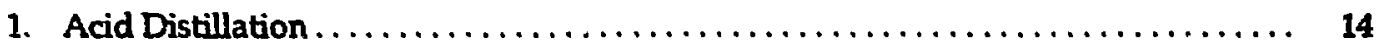

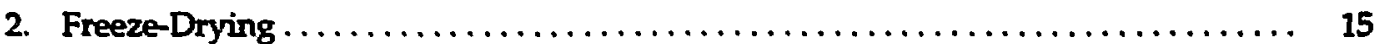

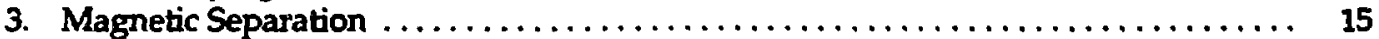

4. Separations Using Ion Exchangers and Extractants $\ldots \ldots \ldots \ldots \ldots \ldots \ldots \ldots \ldots, 16$

5. Nitrate Destruction $\ldots \ldots \ldots \ldots \ldots \ldots \ldots \ldots \ldots \ldots \ldots \ldots \ldots \ldots \ldots, 16$

6. Organics Destruction $\ldots \ldots \ldots \ldots \ldots \ldots \ldots \ldots \ldots \ldots \ldots \ldots \ldots \ldots \ldots, 16$

7. Otner Useful Concepts $\ldots \ldots \ldots \ldots \ldots \ldots \ldots \ldots \ldots \ldots \ldots \ldots \ldots \ldots \ldots \ldots \ldots \ldots \ldots, 17$

V. WASTE MINIMIZATION THROUGH SOLID WASTE STREAM SEGREGATION $\ldots \ldots \ldots, 17$

VI. RESOURCE REQUIREMENTS AND COMIPLIANCE REQUIREMENTS $\ldots \ldots \ldots \ldots \ldots \ldots$ is

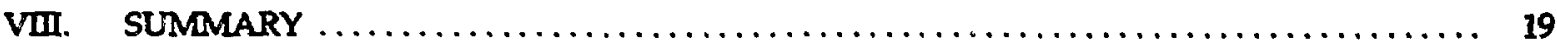

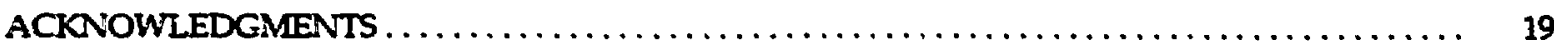

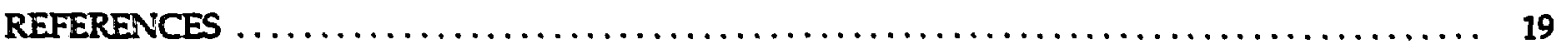

APPENDDX A. TECHNOLOGIES IDENTIFIED

AS VALUABLE TO WASTE MINIMIZATION $\ldots \ldots \ldots \ldots \ldots \ldots \ldots \ldots \ldots, 21$

APPENDD B. WASTE MANAGEMENT: GOVERNING

DOCUMENTS AND REGULATORY COMPLIANCE $\ldots \ldots \ldots \ldots \ldots \ldots \ldots, 25$ 


\section{PREFACE}

Strategic planning to transform an operating plutonium facility into an environmentally benign facility is an extremely challenging task. The plutonium facility at Los Alamos is fortunate to have a pool of talented people who can contribute toward achieving this goal with minimal resources if they are encouraged and supported. All the innovative technical approaches to achieve waste minimization and pollution prevention identified in this report came from the people at TA-55. Because of resource limitations, we are able to pursue only a small fraction of new ideas for waste minimization proposed by investigators within the Laboratory. New initiaitives to implement facility-wide waste management and waste minimization strategies will be identified in future versions of this document.

Maintaining a viable plutonium facility in compliance with all applicable environmental regulations is a challenge to the weapons complex community and requires both innovations and investments in new technologies. In the current environment of heightened public concern over nuclear facilities, the goal of becoming an environmentally benign operating facility is also a desirable survival strategy. Therefore, it is important that all stakeholders and customers of the Los Alamos Plutonium Processing Facility recognize the importance of this effort and actively subscribe towards its success. 


\title{
WASTE MINIMIZATION AND THE GOAL OF AN ENVIRONMENTALLY BENIGN PLUTONIUM PROCESSING FACILITY: A STRATEGIC PLAN
}

by

K. K. S. Pillay

\begin{abstract}
To maintain capabilities in nuclear weapons technologies, the Department of Energy (DOE) has to maintain a plutonium processing facility that meeti, all the current and emerging standards of environmental regulations. A strategic goal to transform the Plutonium Processing Facility at Los Alamos into an environmentally benign operation is identified. A variety of technologies and systems necessary to meet this goal are identified. Two initiatives now in early stages of implementation are described in some detail. A highly motivated and trained work force and a systems approach to waste minimization and pollution prevention are necessary to maintain technical capabilities, to comply with regulations, and to meet the strategic goal.
\end{abstract}


It is recognized that waste reduction and pollution prevention are essential strategies for the continued operation of TA-55, the plutonium processing facility at Los Alamos. The management of TA-55, the Nuclear Materials Technology (NMT) Division, is committed to a program of systematically improving waste minimization activities. This commitment is not only to comply with applicable environmental laws, but to achieve the goal of reducing radioactive discharges from the facility and radioactive, mixed, and hazardous wastes produced to an absolute minimum, and more than meet the requirements of all environmental regulations. The goal of operating a plutonium processing facility that is environmentally benign is extremely challenging. However, this goal is worth pursuing and can probably be achieved through the cooperation and contributions of the whole TA-55 community. While all the technologies necessary to achieve this goal are not yet perfected for plant-wide application, an extensive technology base does exist that can be brought to bear on this problem and can achieve the near-zero-discharge concept.

At the present time, the amount of radionuclides in air emissions from TA-55 is reported to be minuscule, and the facility is in full compliance with all applicable regulations. Nevertheless, efforts are ongoing to further reduce and control stack emissions from TA-55. Liquid waste streams from TA-55 have the potential to comply with all regulatory requirements for radionuclide discharges through the integration and use of liquid-polishing technologies developed at TA-55 and elsewhere. Ongoing efforts to incorporate nitric and hydrochloric acid recovery and reuse into the liquid waste stream processing scheme at TA-55 will contribute greatly to the reduction of dissolved constituents. Technologists at TA-55 seem confident they can reduce the radioactive nuclides in liquid discharges from TA-55 to current standards through a judicious combination of perfected and evolving technologies. A major technical chalienge is to meet clean water standards for aqueous effluents from TA-55 by removing all the nonradioactive constituents from the liquid waste streams. Details of an integrated approach to liquid stream polishing are discussed in Section V of this report.

Solid waste streams from TA-55 that contain traces of plutonium as contaminants are managed in accordance with applicable regulations as transuranic. (TRU) waste and low-level wastes (LLW). Solid waste stream sorting to remove nonradioactive wastes and polishing to remove trace levels of actinides are highly desirable concepts to convert most or all TRU waste streams into low-level wastes that can be managed in on-site landfills. Several technological challenges must be met before solid waste polishing can be achieved and implemented. Ongoing research efforts at TA-55, such as development of electropolishing and fluoride volatilization technologies, are promising, but additional efforts are necessary to recover and recycle plutonium from a number of contaminated solid waste forms. Efforts to develop technologies to maximize the recovery of transuranics from solid waste streams (such as laboratory trash, clothing, gloves, and tools) are prudent investments to achieve the strategic goal described earlier. A new initiative to 
reduce contaminated solid wastes from TA-55 is discussed briefly in Section VI of this report.

\section{A. Relevance of This Plan to the Laboratory's Strategic Directions and Goals}

This NMT Division Strategic Plan can serve the goals of a number of the Strategic Directions of the Laboratory under the Nuclear Materials Subsector and is highly relevant to the Laboratory's "Institutional Plan" for waste minimization and environmental protection.1,2 Specifically, this plan or an equivalent is essential to achieving the goals of Strategic Direction 2 (subsection 4) under the Nuclear Materials Subsector. Technologies demonstrated for TA-55 waste reduction can equally serve the goals of Strategic Directions 1 and 3 under the Nuclear Materials Subsector.

An effort to systematize waste reduction efforts at TA-55 will also contribute to meeting the requirements by the Regents of University of California (as stated in Appendix-F, Section A, 6b. of the 1992 contract).

\section{B. Potential Benefits of Applying New Technologies to External Programs}

One of the majo: challenges facing the Department of Energy (DOE) is the deactivation of some of the facilities as the weapons complex is downsized. A key prerequisite to facility deactivation and environmental restoration is the development of an integrated approach that comprehensively addresses the issue of large quantities of plutonium and other materials contained in residues that are hazardous and/or toxic. Environmental restoration programs at DOE sites need the technical capability to evaluate the nature of existing residues, custom-design processes that are able to remove all the plutonium from the residues, and stabilize both the plutonium fractions for storage and the wastes for disposal. The abilities of research teams at Los Alamos to apply current technologies and develop advanced technologies will be required to safely store some of the difficult-to-manage residues that are now in storage at several locations within the weapons complex. ${ }^{3,4}$ Such initiatives will also enhance the Laboratory's technical base for the plutonium complex of the future.

\section{IL WASTE MINIMIZATION STRATEGIES}

A variety of approaches to reduce waste can be conceived and implemented. However, the success of these efforts requires the full support of the work force both when the concept is being developed and when it is implemented. A wellpublicized waste minimization program that is developed with input and support from operators, mechanics, technicians, and process engineers is the key to success in achieving the idealized goal of a zero-environmental-impact facility. Initiatives 
relevant to implementing a meaningful waste minimization program include the following steps:

(1) Understand the types and amounts of waste generated.

A detailed waste-form analysis can systematically define the scope and magnitude of the effort required to address the problems. The analysis will also identify the waste forms that will lend themselves to volume reduction, treatment for plutonium recovery, and categorization as LLW.

(2) Track facility waste generation.

A waste-tracking system will show the progress made as improvements occur, point out future areas for reduction efforts, and show potential waste reductions as process and equipment changes are made to the facility.

(3) Promote communication between waste generators and n'aste managers.

This step is essential to maximize the results of a waste minimization program. A mutual understanding of the problems associated with waste generation as well as the problems associated with handling and disposal of wastes is important. Such communication helps in identifying waste types and ainounts for reduction. A formal communication system, such as having both waste generators and managers on a joint waste-minimization team, can lead to improved waste reduction while ensuring good contamination control and low personnel exposure.

(4) Find suitable alternatives for many process chemicals that will prevent wastes from being classified as mixed wastes or find an approved mixed-waste treatment process.

Mixed wastes, which contain both radioactive and hazardous constituents, are probably the most difficult waste-handling and disposal problem at the present time. Often, the regulatory requirements for hazardous waste management directly conflict with requirements for the safe handling and disposal of radioactive wastes. Segregation and concentration of hazardous wastes may also contribute to waste minimization and to the goal of a zero-environmental-impact facility. Most of the contributions to this goal have to come from people who are at the process lines and who can suggest and practice simple, safe, and innovative approaches to modify current work habits. 
(5) Reduce waste materials of all types generated at a plutonium facility.

This step will naturally follow when new technologies are in place, innovations by personnel have been incorporated into processes, and the goal of a zero-environmental-impact facility has become a general commitment.

\section{APPROACHES TO WASTE REDUCTION AT TA-55}

The order of the waste management hierarchy at TA-55 is waste generation, segregation, recovery and recycling, treatment, and disposal. Waste minimization strategies can be introduced on all tiers of this hierarchy. Key elements of a viable waste minimization strategy are (1) planning, (2) channeling of resources, (3) work force training, and (4) implementing through teamwork. General approaches to waste reduction are administrative controls, modification of plutonium process technologies, and providing additional treatment of wastes before they leave the facility. The following is a partial list of specific contexts in which waste minimization efforts at the plutonium processing facility at Los Alamos may be approached.

1. A motivated work force trained in the concepts of waste minimization is necessary for any waste minimization effort. Both incentives and training are necessary to develop a motivated work force.

2. A database of past waste generation activities that is specific to unit processes is highly desirable. Such a database would make it possible to institute a systems approach to waste reduction and waste elimination. In the absence of such a database, a conscious effort should be initiated to gather data that can help toward this goal.

3. Waste generation is typically related to the overall housekeeping standards maintained in the facility. An uncluttered process containment area and immediate surroundings can go a long way in reducing waste generation should a dispersion of plutonium occur.

4. It is recognized that uncontaminated room trash from the plutonium processing building (PF-4) is often mixed with other solid waste streams, especially LLW. A room trash characterization, including the separation of items $>100 \mathrm{nCi} / \mathrm{g}$ (nanocuries per gram) from "clean trash" may be instituted. An exploratory effort is underway to sort PF-4 solid waste streams to separate nonradioactive wastes from radioactive wastes.

5. A comprehensive effort to replace the use of paper with computer terminals within plutonium processing areas for such things as data sheets, safe 
operating procedures, and daily administrative checks may be examined as an efficient way to do work and a potential waste reduction alternative.

6. Maintenance work on plutonum-processing equipment is a major waste generator. A review of the rnethods and procedures used for equipment repair may help toward waste minimization. Equipment needing frequent repair or replacement should be replaced with improved systems or be completely redesigned.

7. Occasional contamination of personnel and subsequent cleanup operations are major causes of waste generation. Frequent and thorough personnel monitoring can generally minimize contamination spread within and outside plutonium-processing areas. Redesign of alpha-monitoring systems may help improve timely detection of contamination, thus eliminating the need for extensive cleanup.

8. Decontamination of space and equipment generates voluminous contaminated waste streams. However, it is possible in some instances to design the decontamination activity so that the contaminated equipment is recycled and the plutonium in the residues is recovered.

9. Leaks from facility process-liquid piping systems can generate large amounts of waste. The more flanges, valves, and other piping breaks used in the process, the greater the probability of such leaks. Waste generation from piping leaks can be reduced by minimizing the number of pipes outside the glove boxes and using a double containment for any pipes exposed to the process environment.

10. The replacement of contaminated glove boxes with new ones is a highvolume waste generation activity. Before replacing old glove boxes with new ones, the potential for waste generation ought to be carefully evaluated before deciding on large-scale removal of glove boxes when process changes are instituted.

11. Locating high-maintenance equipment outside glove boxes can significantly reduce waste generation. Examples include glove box lights, motors, actuators, or any other equipment not containing process materials.

12. One of the waste generation functions at a plutonium processing facility is cleanup for the purpose of Special Nuclear Materials (SNM) accountability or criticality control. Frequency of these cleanup operations can be reduced by improving plutonium containment and assay accuracy and recycling the cleanup materials. 
13. Bag-in and bag-out operations often generate significant amounts of plastic waste. Modern bagless transfer devices may be an alternative to existing bag in/bag-out systems.

14. Glove-port design and location are recognized as features that can help reduce wastes. I.ocation of glove ports for easy maintenance of equipment reduces the need for removing windows. Using glove change-out designs that push old gloves into the box prevents containment breakage and lowers the risk of a plutonium release and the resultirig cleanup.

15. Occasional leakage of gloves and the subsequent contamination of the workers and laboratory area is a recognized problem. A well-designed statistical sampling program followed by a protocol for periodic replacement of gloves can go a long way in reducing this problem.

16. A centralized waste sorting, transfer, and treatment glove box can improve waste-handling efficiency and reduce waste generation. Use of a waste trolley to connect the process to the waste-handling glove box is recognized as another way of reducing wastes. Better segregation of wastes can also improve assay accuracy by minimizing matrix-related errors.

17. Centralized sample analysis to support process operations, in conjunction with pneumatic sample transfers from the process areas, is another feature that can help reduce waste generation.

18. Bringing packaging materials and unnecessary supplies into a contaminated area generates unnecessary wastes. This could be avoided by designating outside areas for packing and unpacking.

19. HEPA (high efficiency particulate air) filters used in plutonium-processing facilities are a major source of voluminous wastes. Internally recycling the filters or reducing the amount of plutonium contamination on the filters (which would convert them to LLW) are two alternatives that could significantly reduce this waste form.

20. When glove box windows are changed, old windows are discarded as waste. This practice can be reviewed to see if windows can be reused. The use of unbreakable, thin, nonetching, transparent inner windows that could be retained during the replacement of broken glass windows is also worth considering.

21. Large utility pumps serving the plutonium facility require frequent oil changes. This used oil is the major source of spent lubricants at TA-55. A system redesign or a different oil recycle system may be examined. A new system capable of maintaining the oil viscosity and reducing the radioactive contamination of lubricating fluids may be examined. 
22. Waste assay instruments that can idertify both isotopic composition and quantities of plutonium in one step could be used to sort wastes into ordinary garbage, L.LW, and TRU waste. In addition to reducing the cost of waste handling, these instruments could make a significant contribution to waste reduction.

23. Future process designs should include a detailed examination of waste generation and treatment. Establishing such procedures at the introduction of new processes would help toward waste reduction. Future start-up review teams should include persons well conversant with waste management at TA-55.

24. A systematic quality assurance component that would review all equipment and materials entering plutonium processing areas could prevent the entry of unacceptable materials that would create mixed wastes.

25. A meaningful training program that informs, excites, and motivates a work force to become stakeholders in the waste-minimization effort and contribute to the strategic goal for the facility is a necessity.

\section{RESEARCH AND DEVELOPMENT (R\&D) INITIATIVES}

Several technologies that show promise for waste reduction must have programmatic support before any further development and adaptation can be done. In addition, technologies that have been routinely used in other industries, such as plasma decontamination (from the semiconductor industry), magnetic separation (from the ceramics industry), freeze-drying (from the food processing and pharmaceutical industries), and the use of magnetite beads coated with ion exchangers (from the copper industry), can be adapted and integrated with new technologies that show promise. The programmatic objective is to examine the potentials of these technologies, independently and in combination, to solve the waste stream polishing problems at TA-55. Developing modified flow sheets for plutonium processing, waste polishing, and clean waste generation will be part of this strategy.

Liquid and solid waste stream polishing to remove final traces of plutonium and hazardous chemical constituents is possible through a combination of approaches and technologies identified below.

- $\quad$ Process flow sheet modifications

- Use of alternative chemicals and sorbents for removal

- Nitric and hydrochloric acid recovery and recycling

- Liquid stream polishing using ion exchangers

- Elimination of organics from wastes using supercritical carbon dioxide and/or supercritical water 
- Combined oxidation and salt distillation

- Cryogenic compaction

- Electropolishing

- Hydride/dehydride processing for removing surface layers of plutonium

- Gas-phase fluoride processing and decontamination

- Carbon tetrachloride destruction

- Magnetic separation

- Dry machining

- Oxidative thermal treatment (molten salt oxidation)

- Freeze-drying

The liquid waste effluents from TA-55 can be polisined through the judicious combination of some of the technologies listed above. A systematic approach to accomplishing liquid waste stream polishing can eventually lead to the generation of an aqueous waste stream that is clean and environmentally benign. Such clean water can be reused at TA-55, and excess water can be directly released to the environment without processing outside TA-55.

Polishing solid waste streams is even more challenging, and technology development and resource invesiments are necessary to achieve the ideal goal of a zero-environmental-impact facility. Solid waste minimization efforts are apt to bring faster near-term results than solid waste stream polishing. Parallel efforts to adopt new technologies for reduction in waste generation and application of waste stream polishing technologies to remove plutonium contanination from disposable solids can result in significant reductions in TRU waste streams from TA-55.

\section{A STRATEGY FOR LIQUID WASTE STREAM POLISHING}

Liquid waste streams from TA-55 are the waste streams that carry most of th? actinides and oxic substances. Low-level liquids generated by operations in the Plutonium Processing Facility are categorized as:

- Industrial waste, coming from PF-4 sumps, safety showers, sinks, and janitor drains, that is under $10^{\text {n }} \mathrm{dpm} / \mathrm{l}$ (disintegrations per minute per liter);

- Process acid coming from evaporator distillate, wet vacuum seal overflow, and negative chilled-water overflow that is under $10^{8} \mathrm{dpm} / 1$; and

- Process caustic coming from neutralized chloride solution filtrate and peroxide kill filtrate that is under $10^{19} \mathrm{dpin} / 1$. 
These liquids are assayed to verify activity levels before they are transferred to TA-50 for treatment and disposal. These liquid streams contain a variety of salts, some of hich are considered highiy undesirable in the environment even in minute concentrations.

\section{A. Goals and Objectives}

As part of strategic planning, the TA-55 technical community developed a consensus that radioactive nuclides and RCRA (Resource Conservation and Recovery Act) hazardous constituents in liquid discharges from TA-55 can be reduced to meet current environmental stanciards through a judicious combination of perfected and evolving technologies. Several of these technologies are now ready for plant-wide application at TA-55. However, there are still major technical challenges to be met before all radioactive and hazardous constituents of liquid waste streams can be removed to meet generally accepted clean water standards for aqueous effluents. This section briefly describes the initiatives required to address the liquid waste stream problems at TA-55 so that regulatory requirements can be met and a major strategic gonl for the plutonium facility can be gradually achieved.

The initial goals of this initiative are to:

- Reduce TRU activity in both acid and caustic process waste streams to $<10^{\text {h }} \mathrm{dpm} / \mathrm{l}$;

- Reduce TRU activity level in TA-55 cement drums to $<0.56 \mathrm{~g}$ of weapons-grade plutonium or $<0.0105 \mathrm{~g}{ }^{241} \mathrm{Am}$ per drum (Class C LLW criteria);

- Obtain performance data and permitting for an interim waste form that will meet evolving Environmental Protection Agency (EPA) standards and current Waste Isolation Pilot Plant (WIPP) Waste Acceptance Criteria;

- Reduce acid concentration in acid discard by $90 \%$ and reduce nitrate concentration by a factor of 10 ;

- Increase waste loading per cement drum by $30 \%$; and

- Eliminate the problem of organic solvents.

To achieve these goals, a variety of techniques will be employed, such as reducing the volume of the stream or removing, destroying, recycling, or immobilizing the hazardous component. The benefit of achieving these goals is that the environmental and safety impacts of liquid waste discharges from nuclear materials processing will be dramatically reduced. This reduction will also reduce long-term waste management and storage costs. Also, it is possible that spinoff 
technologies will be developed that can and other industrial waste management efforts.

\section{Near-Term Objective}

In recognition of resource limitations, our plans are to implement this strategy in several discrete phases. The near-term (within the next three years) objective of the strategic initiative of NMT Division is to reduce the hazardous constituents of liquid waste streams from plutonium processing to an acceptable level as defined by law so that these liquids can leave the boundary of the plutonium facility for further processing.

As a part of the planning process for determining the requirements for processing liquid waste, the overali space and throughput requirements need to be defined. Over the past several years the volume of liquid process has declined as a consequence of (1) the introduction of the Advanced Testing Line for Actinide Separations (ATLAS) and (2) the restrictions on mixed-waste generation at TA-55 because of the FFCA (Federal Facilities Compliance Act). Therefore, any waste polishing strategy should be designed to handle the maximum volume produced by the facility in earlier years to ensure proper sizing. During the period 1983-1986, the volume of acid waste streams averaged 160000 liters per year, and the caustic stream averaged about 50000 liters per year. We estimate that the near-term performance goals are achievable within a three-year period assuming that funding is available at the required levels. Depending on available resources, the program will be phased in by stages. In the near term, it is possible to incorporate a new fractional distillation column to the nitric acid waste stream processing and recover almost $99 \%$ of the residual acid from the waste stream. The chloride line, on the other hand, will require a considerable initial investment to design, build, and bring on-line a similar acid recovery operation.

\section{Long-Term Objective}

The long-term (within the next six years) objective of NMT Division is to implement alternative flow sheets and liquid stream polishing technologies as an integral part of TA-55 operations and thereby reduce the radioactive and hazardous constituents of liquid waste streams from TA-55 so that several constituents of the waste streams can be secycled and the remainder can be directly released to the environment without causing any environmental damage. To meet this long-term objective, the alpha activity of the liquid waste stream must be reduced to a few picocuries per liter and all the RCRA hazardous constituents must be reduced to meet EPA guidelines.

\section{Technology Demonstration Efforts}

It is important that NMT Division maintain a reasonable level of R\&D efforts and technology demonstration efforts for waste polishing activities. Many new 
concepts can be adapted to achieve the long-term goal of converting the TA-55 operation into an environmentally benign operation. A detailed list of technologies identified as valuable to waste minimization and pollution prevention may be found in Appendix A of this report. Technologies such as magnetic separation, freeze drying, use of improved ion exchangers, and electrolytic destruction of nitrates and organics are just a few examples. NMT Division has the nucleus of many of these technologies. However, in recent years, inadequate resource allocations have made it impossible to proceed with full development of these technologies for the specific needs of TA-55 operations.

\section{Clean Option}

A conceptual flow sheet of process options for achieving the goal of an environmentally benign plutonium processing facility is shown in Fig. 1 . It is planned to achieve these goals in several phases. During the first three years, acid recovery and recycling will be fully implemented. Also, during that time, freezedrying, nitrate destruction, solid residue stabilization, and other ancillary technologies necessary to implement the second phase will be developed and tested.

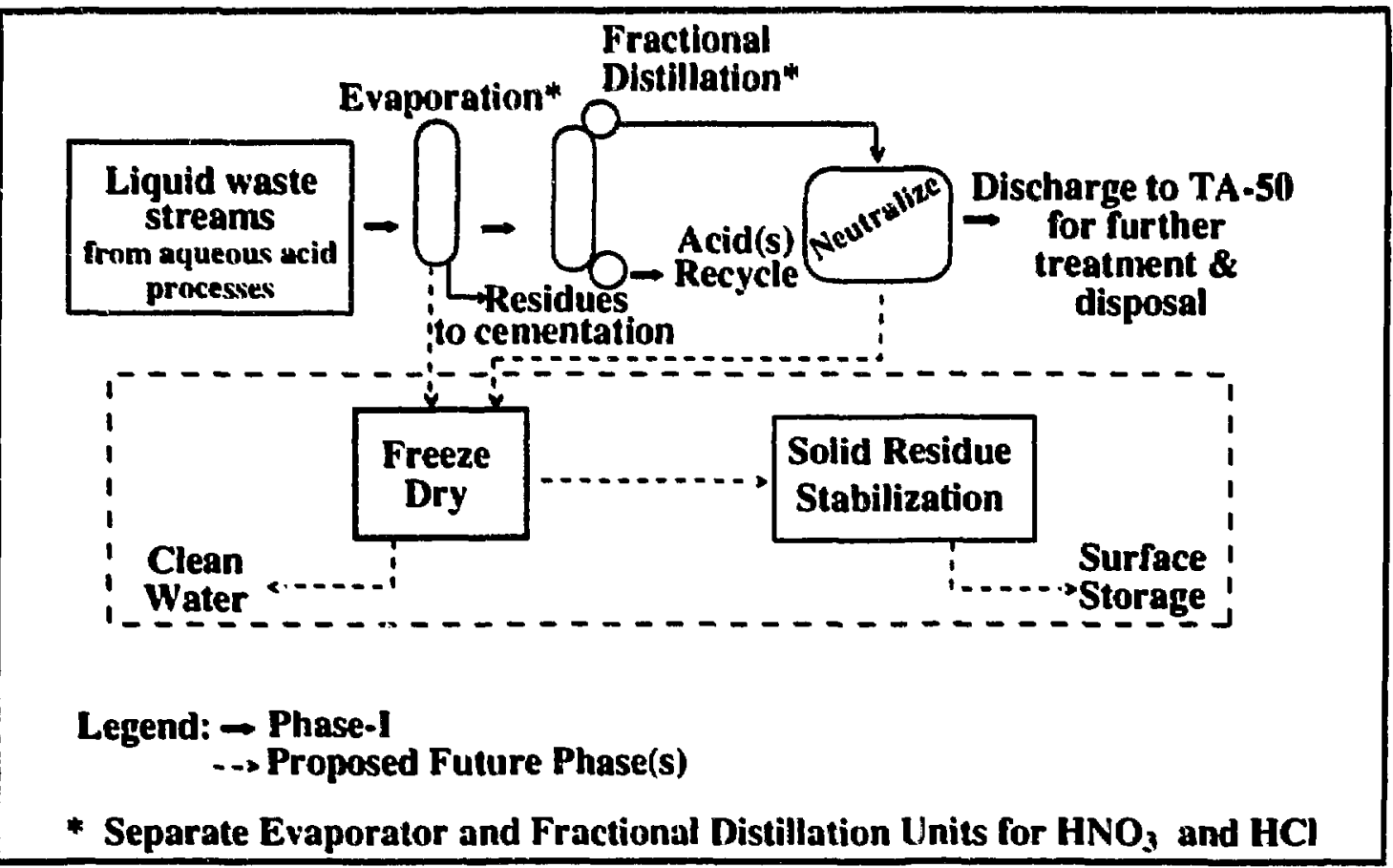

Fig. 1. Conceptual Flow Sheet of an Integrated Liquid Waste Treatment Option for TA-55. 
In the second phase, we hope to demonstrate the feasibility of freeze-drying and of a modified solid residue stabilization approach that will satisfy the requirements of EPA standards for WIPP that are now under development. ${ }^{5} \mathrm{~A}$ steady commitment of resources for the next five years is necessary to achieve this gonl. The major elements of a clean option are:

- Separate acid distillation, recovery, and recycling capability for the nitrate and chloride lines;

- Development, demonstration, and incorporation of freeze-drying technology to convert all solid residues into dry solids and to clean up the water so that it can be recycled within the facility;

- Installation and maintenance of separate process lines for magnetic separation of colloids;

- Chemical or electrochemical processes for organic and nitrate destruction that can be brought on-line as required depending on the waste stream composition;

- Maintenance of a large-scale ion exchange processing system that can be customized to polish different process streams to achieve the goals of the process scheme.

\section{B. Technologies for Waste Stream Polishing}

The following paragraphs contain brief summaries of the technologies being considered for liquid waste stream polishing at the plutonium processing facility.

\section{Acid Distillation}

A standard method to separate constituents of two or more miscible liquids is to use the differences in their boiling points. It is possible to use this principle to recover a significant part of nitric or hydrochloric acid from binary aqueous solutions. The recovery and recycling of nitric and hydrochloric acids can significantly reduce the liquid waste stream from TA-55. A two-stage recovery and recycle process is being considered. First each acid waste stream is evaporated to separate volatiles (primarily acid and water) from dissolved salts. Next, the evaporated acids and water are separated in a fractional distillation column to yield a concentrated acid and a water stream.

The ATLAS nitrate process line already uses a thermosiphon evaporator as an integral part, and a second distillation column is planned as an upgrade to this existing system. 
The Experimental Chloride Extraction Line (EXCEL) process now coming online does not have any acid recovery system. A new two-stage fractional distillation system using Kynar or a similar material in the construction will be designed, built, and installed to serve the EXCEL line. The possibility of adapting a commercially available system for $\mathrm{HCl}$ recovery is currently being pursued.

The advantages of this acid distillation technology include the ability to remove toxic constituents from waste streams and the ability to recover and recycle these acids within the facility.

\section{Freeze-Drying}

Freeze-drying is the removal of a solvent or a volatile component by sublimation from a frozen solution or a multi-component material. This process, also known as lyophilization, is used extensively and on a large scale in the food preservation industry and in the production of a variety of pharmaceuticals. This technology can be adapted to serve the needs of liquid waste stream polishing at TA-55. A cooperative research and development agreement (CRADA) is now being negotiated with an industrial partner to get technical expertise in large-scale lyophilization systems. Preliminary results of bench-scale experiments using this technology to separate dissolved radionuclides from aqueous solutions show the potential for achieving decontamination factors up to $10^{8}$.

Limitations of this technology may include large space requirements to accommodate commercial units. We plan to objectively evaluate the potential of this technology for TA-55 liquid stream polishing through bench-scale experiments. The CRADA partner has offered to provide a lyophilization unit that is designed and built for glove box operation at Los Alamos.

One advantage of this technology is that it does not produce any secondary waste stream and the recovered water can be recycled within the facility.

\section{Magnetic Separation}

Magnetic separation is the physical separation or segregation of components of a heterogeneous mixture on the basis of magnetic susceptibility. This technology is widely used in the ceramics industry to clean up undesirable ferromagnetic constituents of kaolin. Because all actinide compounds are paramagnetic, magnetic separation of actinide-containing mixtures is theoretically possible. Los Alamos (NMT Division) has a CRADA to demonstrate this technology as part of the major environmental restoration program involving several DOE sites.

At Los Alamos, one of the applications of this technology can be to separate the fine actinide-bearing colloidal particles from liquid streams. These particles cannot be separated by conventional techniques, such as ion exchange or filtration. 
Ongoing efforts at NMT-3 will evaluate the potential of this technology for integration with the liquid waste stream polishing flow sheet. An advantage of this technology is that it does not produce any secondary waste stream.

\section{Separations Using Ion Exchangers and Extractants}

lon exchange is a process by which reversible stoichiometric interchange of ions of the same sign takes place between an electrolyte solution and a solid phase. This technology has been well developed over the past 50 years, and there is a large knowledge base that can be used to select materials and systems necessary for our specific application. Variants of this process include a variety of absorbers that are custom made to meet specific process needs. NMT Division has significant expertise in this area, including the ability to design and produce polymer-supported chelating absorbers for ion-specific extraction systems.

The use of ion exchange and absorber technologies for waste stream polishing will be determined by the process operations and the waste stream characteristics. We plan to design ion exchange systems that will adapt easily to use in an integrated cleanup system of liquid wastes from TA-55. The latter approach may be extremely valuable to the new EXCEL process line operations.

\section{Nitrate Destruction}

Nitrates are undesirable in waste streams released to the environment. The use of formic acid to chemically destroy nitrates in liquid wastes is a technology NMT Division is familiar with and has expertise in. Alternative approaches, such as electrolytic decomposition, are being pursued as an R\&D program in NMT-2. The electrolyte decomposition approach, if successful, will allow us to incorporate a technology that in itself does not create secondary waste.

The R\&D effort on nitrate destruction will be vigorously pursued, and a decision will be made at a later date about what will be included in the integrated liquid stream polishing scheme.

\section{Organics Destruction}

Organic compounds, such as chlorofluorocartons, which have been identified by the EPA as undesirables, are being carefully examined for possible elimination from process flow streams at TA-55. However, we plan to develop the means to destroy organics in residues should we need the technology for destroying undesirable organics in the liquid waste stream.

Fractionation followed by combustion is one such scenario with many possible variations to this approach. A parallel effort to develop capabilities for destroying organics will be pursued and perfected. 


\section{Other Useful Concepts}

Many other technologies, most of them pursued at other parts of Los Alamos or at other locations within the DOE complex, may be included in our final flow sheet for liquid waste stream polishing. Examples of such technologies include hydrothermal processing, corona discharge through liquids, and magnetite beads coated with ion exchange and absorber materials. We plan to keep abreast of technology developments in these areas and examine their potential value to TA-55 operations.

\section{WASTE MINIMIZATION THROUGH SOLID WASTE STREAM SEGREGATION}

Recently, a new effort was initiated at TA-55 to reduce the contaminated miscellaneous garbage originating within process areas in PF-4 of the plutonium facility. It is estimated that about $60 \%$ of the miscellaneous solid wastes (paper, rags, plastics, fabrics, etc.) generated from the process areas in PF-4 at TA-55 is nonradioactive. Even so, the waste is currently disposed of as radioactive waste because of its place of origin. An ongoing effort to address this issue and reduce the radioactive solid waste stream from PF-4 uses a segregation and sorting mechanism. The strategy is to place a white-top trash can in each room. Workers voluntarily deposit solid waste in these containers if they think it is nonradioactive. These trash cans are in addition to the yellow- and red-top cans that are already available at PF-4 work areas to sort out highly contaminated solids from all others. The voluntary segregation of presumably nonradioactive wastes is only the first step in our strategy to separate nonradioactive and contaminated wastes.

The second step in this effort is to transfer the white-top cans to a relatively clean area with a low background radiation level and screen the solid wastes with a combination of instruments to sort out the contaminated from the noncontaminated. The present strategy is to spread the miscellaneous solid wastes onto a flat surface, possibly a conveyor belt, and monitor the radioactive emissions from them using a combination of highly sensitive gamma, $x$-ray, neutron, and alpha detectors. If any radiation is detected, those materials will be sorted out as radioactive while the remainder will be segregated as nonradioactive waste. The nonradioactive waste will then be sent to an open landfill instead of a low-level or TRU waste management area. We have deliberately chosen the strategy of creating a solid waste landfill for nonradioactive wastes within fenced areas of the Laboratory to avoid public criticism for sending wastes from process areas to a municipal landfill. However, segregated nonradioactive wastes originating from this sorting mechanism can be disposed of in municipal landfills. The details of monitoring and segregation are now being examined by a group of experts in nondestructive radiation measurement and radioactive waste management. 
The ability to reliably segregate nonradicactive wastes from contaminated wastes would allow disposal of the former in surface landfills. If nearly $60 \%$ of miscellaneous wastes originating from process areas can be segregated and managed as nonradioactive wastes, there will be considerable savings in waste management costs, and in costs involved in long-term storage and surveillance. If this effort proves successful, the approach can be extended to other locations within the laboratory to segregate nonradioactive wastes from contaminated wastes. Other nuclear facilities within the DOE complex have also expressed an interest in this approach to nonradioactive waste segregation and disposal.

\section{RESOURCE REQUIREMENTS AND COMPLIANCE REQUIREMENTS}

An evolutionary plan for minimizing waste from plutonium processing was proposed in 1990 with a detailed discussion of compliance concerns. ${ }^{6}$ At that time various task plans were identified with expected support for technology development as part of Complex-21 initiatives. ${ }^{7}$ With the recent shelving of Complex-21 initiatives by the DOE, resources to develop and adapt technologies for waste minimization are becoming scarce while pressures to comply with regulatory requirements are on the increase. Regulations applicable to waste management and waste minimization at TA-55 are listed in Appendix B of this report.

It is now abundantly clear to everyone that all nuclear facilities within the DOE complex have to comply with all environmental statutes. Mandates of Federal Statutes, Presidential Executive Orders, DOE Orders, EPA Regulations ? nd Standards, and State Regulations require that a concerted effort be directed at compliance with environmental regulations aimed at pollution prevention and waste minimization. However, the steady decline of resources within the nuclear weapons program for support of pollution prevention and waste minimization programs requires us to allocate and manage all available resources intelligently. It is equally necessary to recognize that in the current environment of public concern over nuclear facility operations, the only alternative is to make a concerted effort at regulatory compliance. In the interest of keeping the doors open and maintaining a viable operating facility, an increased share of available resources is necessary. Such an investment can also lead to new technologies that can be used to reach the goal of an environmentally benign plutonium processing facility in the future.

The Laboratory and the New Mexico Environmental Division of the EPA are having ongoing negotiations on a National Environmental Pollutant Discharge Elimination System (NEPDES) permit. Our aqueous waste streams require considerable reductions in soluble chemical and radioactive constituents before meeting the requirements for point-source discharge. The RCRA liabilities to waste generators for environmental pollution make it even more urgent to take a series of definitive actions to move toward meeting the goals of the NEPDES permit. 
Several of the technologies being developed show promise for integration into a total waste reduction and elimination system, but need either basic or additional programmatic support. Integrating these resource requirements into all programmatic efforts is essential.

\section{SUMMARY}

Key elements of a strategy to develop and adopt systems and technologies to reach the goal of transforming plutonium processing at TA-55 into an environmentally benign operation are identified. Whole-hearted support by all segments of the TA-55 population is necessary to achieve this goal. Suggestions to modify and improve these strategic directions are invited from all segments of the TA-55 community. A commitment by the leadership of the technical groups in NMT Division to implement this program and a willingness to convey this commitment to the work force at TA-55 are essential to launching this program and achieving its objectives.

\section{ACKNOWLEDGMENTS}

The author wishes to acknowledge the assistance of Jim Balkey, Steve Yarbro, Tim Hayes, Ron Wieneke, and Kathleen Gruetzmacher of NMT-2 for their suggestions and technical input ir the preparation of this document.

\section{REFERENCES}

1. "Los Alamos National Laboratory Institutional Plan FY 1993-1998," LALP-92-50 (December 1992).

2. "The Strategic Plan Working Document," Los Alamos National Laboratory (January 1993).

3. "Openness Initiative" by the Secretary of Energy, U. S. Department of Energy (December 7,1993 ).

4. "Spent Fuel Working Group Report," Volumes 1-3, U.S. Department of Energy (November 1993).

5. 40 CFR 191 revisions, Federal Register 58 (242), (December 20, 1993).

6. D.C. Christensen, "Waste Minimization Program: Plutonium Waste Stream," LA-12142-MS, Los Alamos National Laboratory (November 1990). 
7. L. Austin, E.M. Hanson, and R. Mah, "Los Alamos Lead Laboratory Program Plan - Pu Processing," predecisional draft, Los Alamos National Laboratory (September 1992). 


\section{APPENDIX A}

\section{Technologies Identified as Valuable to Waste Minimization}

\begin{tabular}{|c|c|c|}
\hline Topies & Strategies & Key Elements \\
\hline $\begin{array}{l}\text { 1. Waste Stream } \\
\text { Database Development }\end{array}$ & $\begin{array}{l}\text { a) Gather historical data } \\
\text { before moratorium }\end{array}$ & $\begin{array}{c}\text { use of OS-2 and NMT-4 } \\
\text { database }\end{array}$ \\
\hline & $\begin{array}{l}\text { b) Compare with process } \\
\text { line operator estimations }\end{array}$ & \\
\hline & c) Establish a baseline & \\
\hline & $\begin{array}{l}\text { d) Start new database for all } \\
\text { waste streams from TA-55 }\end{array}$ & \\
\hline & $\begin{array}{l}\text { e) Develop process-specific } \\
\text { waste streams }\end{array}$ & \\
\hline & & \\
\hline 2. Mixed Wastes & a) Minimize generation & \\
\hline & $\begin{array}{l}\text { b) Eliminate hazardous } \\
\text { components }\end{array}$ & $\begin{array}{l}\text { residual radioactive } \\
\text { components }\end{array}$ \\
\hline & & alternatives for reagents \\
\hline & $\begin{array}{l}\text { c) Review of materials } \\
\text { entering the facility }\end{array}$ & \\
\hline & & \\
\hline 3. Liquid Wastes & a) Minimize generation & process efficiency \\
\hline & & waste stream polishing \\
\hline & & acid recycle \\
\hline & & chelating ligands \\
\hline & $\begin{array}{l}\text { b) Polish liquid waste } \\
\text { streams }\end{array}$ & ion exchange \\
\hline & & molecular sieves \\
\hline & & other absorbers \\
\hline & $\begin{array}{l}\text { c) Demonstrate feasibility/ } \\
\text { performance at nitrate } \\
\text { process line (ATLAS) }\end{array}$ & \\
\hline
\end{tabular}




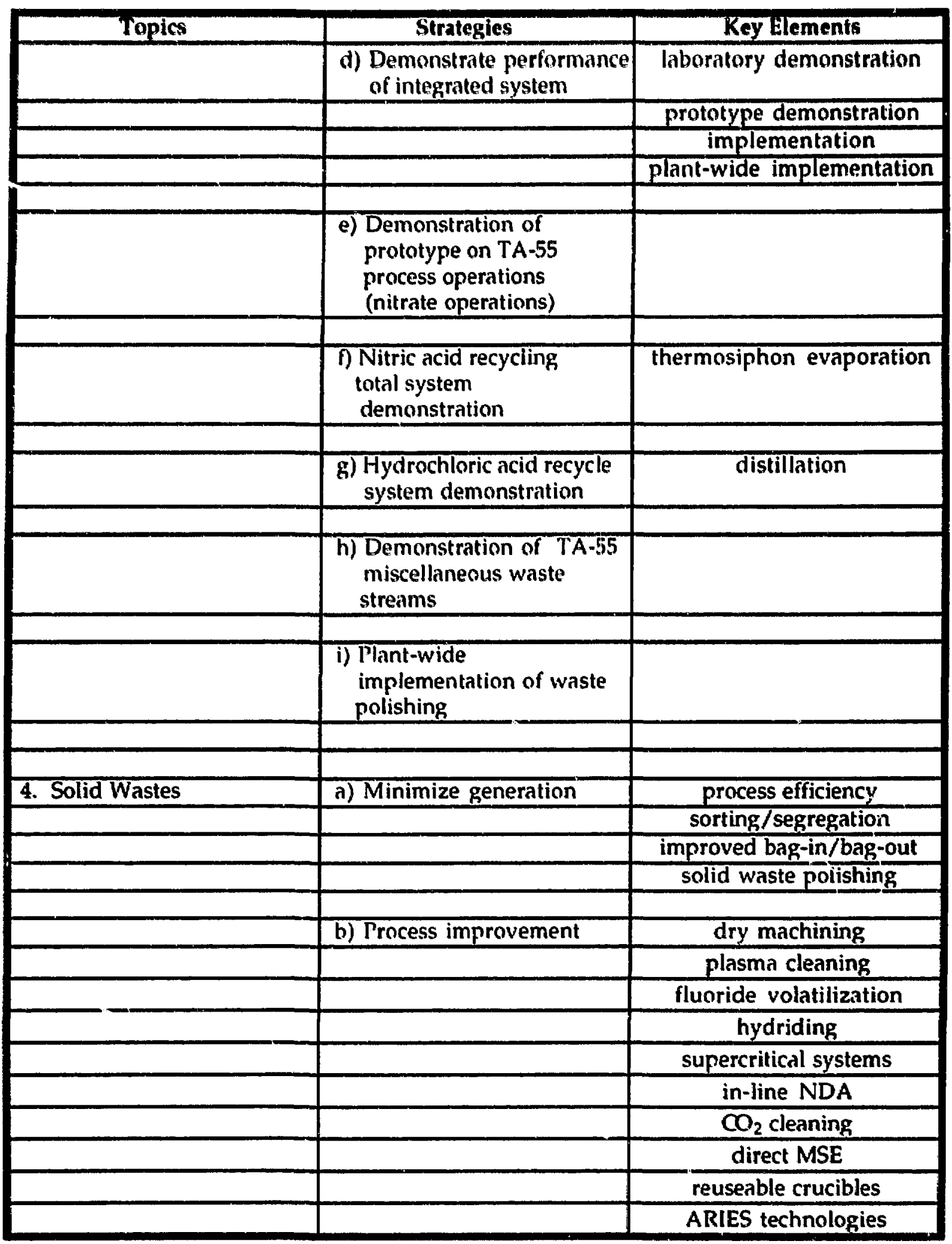




\begin{tabular}{|c|c|c|}
\hline \multirow[t]{3}{*}{ Topics } & Stralegies & Key Elements \\
\hline & $\begin{array}{l}\text { b) Process improvements } \\
\text { (continued) }\end{array}$ & other technologies \\
\hline & & \\
\hline & c) Sorting/segregation & develop strategy \\
\hline & & trial/evaluation \\
\hline & & implementation \\
\hline & $\begin{array}{l}\text { d) Improved bag-in/bag-out } \\
\text { systems }\end{array}$ & evaluate bagless systems \\
\hline & & evaluation \\
\hline & & installation \\
\hline & & \\
\hline & $\begin{array}{l}\text { e) Solid waste treatment } \\
\text { technology development }\end{array}$ & plasma decontamination \\
\hline & & supercritical extraction \\
\hline & & other \\
\hline & & \\
\hline & f) Decontamination & electropolishing \\
\hline & & flucride volatility \\
\hline & & supercritical $\mathrm{CO}_{2}$ cleaning \\
\hline & & \\
\hline & g) Paper waste reduction & $\begin{array}{c}\text { compute.ization of SOPs, } \\
\text { DACs, etc. }\end{array}$ \\
\hline & & \\
\hline $\begin{array}{l}\text { 5. Gaseous or Airborne } \\
\text { Wastes }\end{array}$ & $\begin{array}{l}\text { a) Monitoring and database } \\
\text { development }\end{array}$ & \\
\hline & b Scrubbing streams & $\begin{array}{c}\text { waste-streain-specific } \\
\text { scrubbers }\end{array}$ \\
\hline & & \\
\hline & c) Continuous monitoring & $\begin{array}{l}\text { install continuous } \\
\text { monitoring system }\end{array}$ \\
\hline & & \\
\hline
\end{tabular}




\title{
APPENDIX B
}

\section{WASTE MANAGEMENT: \\ GOVERNING DOCUMENTS AND REGULATORY COMPLIANCE}

\author{
Kathleen Gruetzmacher, NMT-2
}

\section{Introduction}

This appendix is a brief summary of the documents used in managing waste at the Los Alamos National Laboratory Plutonium Processing Facility (TA-55) to ensure compliance with regulations. The Nuclear Materials Processing Nitrate Systems Group (NMT-2) has the responsibility for waste management operations at TA-55. This appendix enumerates the documents that govern day-to-day operations. The information is divided into the following categories:

- RCRA/Hazardous Material Management

- Waste Characterization/Classification and Certification

- Waste Minimization/Pollution Prevention

- Waste Operations

- Waste Storage

- Waste Disposition (Shipment and IntraLab Transfers)

- Airborne Emissions

- Liquid Waste Management

- Control of Toxic Substances

- Management of Spills

A hierarciny of waste management documents currently in use at TA-55 is shown in Table B-1 at the end of this Appendix.

\section{RCRA/Hazardous Materials Management}

Hazardous waste at TA-55 is handled in accordance with the Resource Conservation and Recovery Act (RCRA) as administered by the U.S. Environmental Protection Agency (EPA) and the New Mexico Hazardous Waste Management Regulations (NMHWMR).

A short synopsis of these regulations is contained in the Laboratory Environment, Safety, and Health Manual in the administrative requirement entitled "Hazardous and Mixed Waste" (AR 10-3). 
The Laboratory Director's Policy (DP 105) entitled "Hazardous and Radioactive Waste Management and Minimization" is the Laboratory policy statement on handling waste.

Instructions specific to TA-55 on the handling of hazardous waste are contained in the "TA-55 Waste Management" procedure (539-GEN-R00).

\section{Waste Characterization/Classification and Certification}

Waste characterization is done either by chemical analysis or knowledge of process. Those who generate waste use the Waste Profile Form (WPF) to describe the waste and to request analysis of unknown wastes. This information is used by the treatment/storage/disposal facility that receives the waste. This form and instructions for completing it are in AR 10-9 of the Laboratory Environment, Safety, and Health Manual. The Laboratory's "Interim Status Waste Analysis Plan for Mixed Waste," which is in draft form, is used to determine how to analyze mixed waste.

Certification of radionctive waste is done according to various Waste Acceptance Criterion (WAC). The governing WAC for transuranic (TRU) waste is the Waste Isolation Pilot Plan (WIPP) WAC. The Laboratory's secondary governing documents for TRU waste are the

- $\quad$ "LANL TRU Waste Certification Plan" (WCP-HSE7-CP-01, R05) and

- "Safe Storage Waste Acceptance Criteria for Transuranic (TRU) Waste at TA-54, Area C'" (AP.2-EM7G-027, R.1, currently in draft form).

The Laboratory's governing document for certification of low-level waste (LLW) is the "Los Alamos Waste Acceptance Criteria for Solid Low-Level Radioactive Waste Disposal at TA-54, Area G" (RAD-EM7-AD-02, R01).

TA-55-specific instructions for certification of waste are included in the following procedures:

- Inspection and Packaging Combustible and Noncombustible Transuranic Waste for WIPP" (TRU-NMT2-DP-01, R05),

- "Certification of Waste for Cement Fixation" (TRU-NMT2-DP-12, R00), and

- $\quad$ "Handling of Nonroutine, Low-Level and Mixed Waste" (414-GEN7, R03).

Low-level waste procedures are currently being revised to ensure that they comply with the Laboratory's Low-Level Waste Acceptance Criteria. 
ara

The governing documents for waste minimization and pollution prevention

- the Laboratory "Waste Minimization and Pollution Prevention Awareness Plan" and

- the Laboratory Environment, Safety, and Health Manual administrative requirement "Waste Minimization" (AR 10-8).

These documents are based on

- DOE order 5400.1, "General Environmental Protection Program,"

- DOE order 5400.3, "Hazardous and Radioactive Mixed Waste Program,"

- DOE order 5820.2A, "Radioactive Waste Management," and

- RCRA.

TA-55 is operating under these governing documents and this strategic plan. A TA-55 Waste Minimization and Pollution Prevention Plan is in draft form.

\section{Waste Operations}

Waste operations at TA-55 are performed in accordance with the requirements of

- DOE Crder 5820.2A, "Radioactive Waste Management,"

- DOE Order 5400.3, "Hazardous and Radionctive Mixed Waste Program,"

- DOE Order 5700.6B, "General Operations Quality Assurance,"

- Standards from ANSI/ASME NQA-1, "Quality Assurance Program Requirements for Nuclear Facilities,"

- RCRA, and

- the EPA Clean Water Act.

Laboratory documents used in this program are administrative requirements and technical bulletins of the Laboratory Environment, Safety, and Health Manual. These include:

- $\quad$ "Radioactive Liquid Waste" (AR 10-1),

- $\quad$ "Radioactive Liquid Waste Collection System" (TB 1001),

- "Radioactive Liquid Waste Treatment and Disposal" (TB 1002),

- $\quad$ "Low-Level Radioactive Solid Waste" (AR 10-2), and

- $\quad$ "Transuranic (TRU) Solid Waste" (AR 10-5). 
TA-55 piocedures specifically governing the management of waste at TA-55 are

- the TA-55 Waste Management procedure (539-GEN-R00),

- $\quad$ Inspection and Packaging Combustible and Noncombustible Transuranic Waste for WIPP" (TRU-NMT2-DP-01, R05),

- "Certification of Waste for Cement Fixation" (TRU-NMT2-DP-12, R00),

- $\quad$ "Handling of Nonroutine, Low-Level and Mixed Waste" (414-GEN7, R03),

- "Documentation for Cement Fixation" (TRU-NMT2-DP-14, R00),

- "Auxiliary Activities for Cement Fixation" (TRU-NMT2-DP-11, R00),

- "Cement Fixation of Process Residues in 55-Gallon Drums," (TRUNMT-2-DP-04, R00),

- $\quad$ "Disposal of Nonroutine, Solid, TRU Waste" (TRU-NMT2-DP-02, R00),

- $\quad$ "Liquid Waste Management for TA-55" (408-GEN7, R05, in revision), and

- $\quad$ "Handling of Oil from PF-4" (436-NMT7, R02, in revision).

\section{Waste Storage}

Waste is not stored at TA-55 except on a temporary basis (e.g., staging for transportation). Waste generated at TA-55 is stored at TA-54 and governed by the Safe Storage WACs of the Chemical Science and Technology Group CST-7. Hazardous wastes temporarily stored at TA-55 are stored in permitted, satellite, and less-than-90-day storage areas. They are stored according to regulations in the following documents:

- NMHWMR,

- RCRA,

- the Laboratory Environment, Safety, and Health Manual administrative requirement "Hazardous and Mixed Waste" (AR 10-3),

- $\quad$ LANL Director's Policy DP 105, "Hazardous and Radioactive Waste Management and Minimization," and

- TA-55 Waste Management procedure (539-GEN-R00).

Waste Disposition (Shipments and IntraLab Transfers)

Shipping and receiving functions at TA-55 are performed by NMT-4, the Nuclear Materials Measurements and Accountability Group, according to Department of Transportation regulations, Laboratory policies, and NMT-4 procedures. 


\section{Airborne Emissions}

Clean Air Act (CAA) documentation at TA-55 is handled by ESH-8, the Environmental Safety and Health Group, and NMT-8, the TA-55 Facilities Management Group.

\section{Liquid Waste Management}

Clean Water Act (CWA) documentation that is not directly applicable to radioactive liquid waste is handled by NMT-8.

Low-level radioactive liquid waste from TA-55 is sent to TA-50 for processing. It is handled in accordance with the EPA CWA and the following administrative requirements and technical bulletins in the Laboratory Environment, Safety, and Health Manual:

- $\quad$ "Radioactive Liquid Waste" (AR 10-1),

- "Radioactive Liquid Waste Collection System" (TB 1001), and

- "Radionctive Liquid Waste Treatment and Disposal" (TB 1002).

TA-55 procedures related to the CWA are

- TA-55 Waste Management procedure (539-GEN-R00),

- $\quad$ "Liquid Waste Management for TA-55," (408-GEN7, R05, in revision), and

- $\quad$ "Handling of Oil from PF-4" (436-NMT7, R02, in revision).

\section{Control of Toxic Substances}

The Toxic Substances Control Act (TSCA) governs the manufacture and disposal of new hazardous chemicals, bans polychlorinated biphenyls (PCBs) and regulates their disposal, regulates asbestos removal, and regulates indoor radon monitoring. As it applies to TA-55, TSCA is implemented in accordance with the following administrative requirements in the Laboratory Environment, Safety, and Health Manual:

- $\quad$ "Polychlorinated Biphenyls," for PCs (AR 10-4),

- "Low-Level Radioactive Solid Waste" (AR 10-2), and

- $\quad$ "Hazardous and Mixed Waste" (AR 10-3).

Management of Spills

Spills and releases of chemicals are governed by the following:

- the EPA Comprehensive Environmental Response, Compensation, and Liability Act of 1980 (CERCLA), 
- RCRA,

- the Hazardous and Solid Waste Amendments of 1984 (HSWA),

- the "Emergency Planning and Community Right to Know" portion of the Superfund Amendments and Reauthorization Acl of 1986 (SARA),

- the CWA,

- the CAA,

- the NMHWMR, and

- DOE Order 5500.3A, "Emergency Planning and Preparedness for Operational Emergencies."

Laboratory requirements for dealing with spills are contained in

- the Laboratory Environment, Safety, and Health Manual administrative requirement "Accidental Oil, Chemical, and Airborne Releases" (AR 10-4),

- the "Spill Prevention Control and Countermeasure Plan for the Los Alamos National Laboratory" (SPCC),

- the "Interim Status Contingency Plan for Mixed Waste Units," and

- the "Los Alamos National Laboratory Emergency Response Plan."

TABLE B-1

Hierarchy of Documents

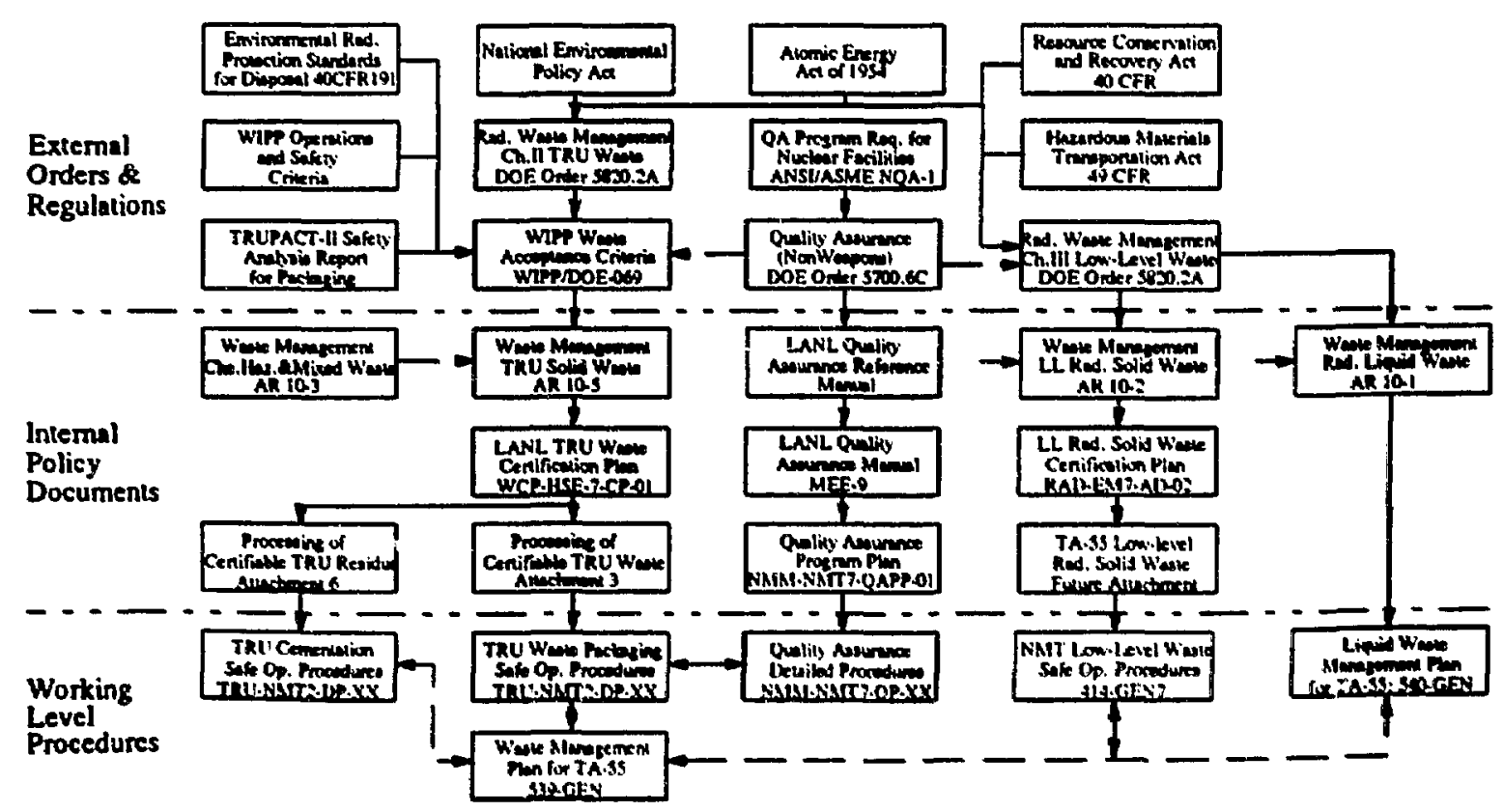

